\title{
Margaret Atwood
}

\section{Er ég vondur femínisti?}

\section{Inngangur að býðingu}

Greinin sem hér fer á eftir á sér nokkra forsögu - og raunar eftirköst líka. Höfundurinn er kanadíska fræðikonan og rithöfundurinn Margaret Atwood, einn fremsti höfundur samtímans, en tilefnið eru atburðir sem áttu sér stað í kanadískum háskóla fyrir fáum árum.

Í nóvember 2015 tilkynntu yfirvöld Háskólans í Bresku-Kólumbíu að Steven Galloway, forstöðumaður ritlistardeildar skólans og pekktur rithöfundur, hefði verið leystur tímabundið frá störfum vegna „alvarlegra ásakana“. Ekki var tilgreint hvers eðlis pessar ásakanir væru en gefið í skyn að málið snerist um kynferðisofbeldi af einhverju tagi. Galloway fékk pó ekki að vita hvað hann var sakaður um og var jafnframt meinað að tjá sig um málið. Í kjölfarið var Mary Ellen Boyd, fyrrum dómara við hæstarétt Bresku-Kólumbíu, falið að rannsaka ásakanirnar og eftir að hún skilaði skýrslu sinni til háskólayfirvalda var Galloway sagt upp störfum í júní 2016 á grundvelli „trúnaðarbrests“ án pess pó að staðfest væri hvort ásakanirnar gegn honum ættu við rök að styðjast eður ei. Skýrsla dómarans var ekki gerð opinber og háskólinn upplýsti ekki um niðurstöður hennar.

Í október 2016 birtist síðan opið bréf til Háskólans í Bresku-Kólumbíu, undirritað af fjölmörgum rithöfundum og áhrifafólki í kanadísku bókmenntalífi, p.á m. Margaret Atwood, par sem málsmeðferð háskólans er harðlega átalin og pess krafist að óháð rannsókn fari fram á málinu öllu. Petta opna bréf olli miklum hræringum meðal kanadískra femínista og bókmenntafólks og segja má að pað hafi með nokkrum hætti klofið kanadískan bókmenntaheim í herðar niður. Undirskriftum var safnað gegn bréfinu og aðstandendur pess sakaðir um að sýna polendum kynferðisofbeldis lítilsvirðingu - og sumir drógu raunar undirskriftir sínar til baka.

Í ársbyrjun 2018 birtist svo eftirfarandi grein Atwood í dagblaðinu The Globe and Mail í Toronto - en í millitíðinni hafði prennt gerst sem máli skiptir: 
Í fyrsta lagi höfðu ýmis atriði úr skýrslu Mary Ellen Boyd lekið í fjölmiðla, m.a. sú niðurstaða hennar að ásakanir á hendur Steven Galloway um kynferðisofbeldi væru tilhæfulausar; í annan stað hækkaði frægðarsól Atwood til muna vorið 2017 pegar sýningar hófust á rómuðum sjónvarpspáttum byggðum á sögu hennar, The Handmaid's Tale; og loks komst \#MeToo-hreyfingin á flug á Netinu pá um haustið. Pessi grein hefur pví ekki síður vakið viðbrögð og flokkadrætti en opna bréfið 2016 og umræðan hefur breiðst út fyrir landamæri Kanada.

\section{Ritstjórar og pýdandi}

Ég er víst „vondur femínisti“. Ég get bætt pví við aðrar sakir sem ég hef verið borin síðan 1972, eins og раð að ég hafi klifið til frægðar upp eftir píramída úr afhöggnum höfðum karla (vinstrisinnað tímarit), að ég sé drottnunarkvendi og staðráðin í að brjóta karlkynið á bak aftur (hægrisinnað rit, meira að segja með teikningu af mér í leðurstígvélum með svipu) og að ég sé óféti sem geti - með galdramætti hvítrar nornar - tortímt hverjum peim sem gagnrýnir mig við kvöldverðarborð í Toronto. Svona er ég skelfileg! Og nú lítur út fyrir að ég sé komin í stríð við konur, eins og vænta mátti af kvenhatandi nauðganamangara og vondum femínista eins og mér.

Hvernig skyldi góður femínisti líta út í augum ákærenda minna?

Grunnafstaða mín er sú að konur séu mannverur, færar um allan pann skala frómrar og fólskulegrar breytni sem pví fylgir, par með talið glæpaverk. Pær eru ekki englar sem ekkert rangt geta gert. Ef svo væri pyrftum við ekkert réttarkerfi.

Ég er heldur ekki peirrar skoðunar að konur séu börn, ófærar um að taka frumkvæði eða siðferðilegar ákvarðanir. Ef pað væri svo, værum við komin aftur á 19. öldina og konur gætu hvorki átt eignir, notað kreditkort, stundað háskólanám, stjórnað barneignum sínum né kosið. Í NorðurAmeríku eru valdamiklir hópar sem stefna í pessa átt en peir eru yfirleitt ekki taldir til femínista.

Par að auki álít ég að til pess að konur geti notið borgararéttinda og mannréttinda verði borgara- og mannréttindi að vera til staðar yfirleitt, par á meðal grundvallarréttarkerfi, alveg eins og pað er forsenda kosningaréttar kvenna að almennur kosningaréttur sé til. Álíta góðir femínistar að einungis konur eigi að hafa slík réttindi? Pað er óhugsandi. Раð væri bara viðsnúningur á gamla fyrirkomulaginu par sem karlarnir sátu einir að peim rétti. 
Gerum pá ráð fyrir að góðu femínistarnir sem ásaka mig og ég, vondi femínistinn, getum sammælst um ofangreind atriði. Hvar greinir okkur á? Og hvernig komst ég í petta klandur gagnvart góðu femínistunum?

Í nóvember 2016 skrifaði ég undir opið bréf undir yfirskriftinni $U B C$ Accountable - rétt eins og ég hef af prinsípástæðum skrifað undir marga aðra undirskriftalista. Í pessu bréfi var kallað eftir pví að Háskólinn í BreskuKólumbíu (UBC) axlaði ábyrgð á pví að í meðferð sinni á máli Stevens Galloway, fyrrverandi deildarformanns ritlistardeildar, brást háskólinn hrapallega og pað sama má segja um meðferð hans á peim sem gerðust meðkærendur í málinu. Málavextir voru peir að fyrir nokkrum árum gerði háskólinn málið opinbert í fjölmiðlum áður en rannsókn hafði farið fram og meira að segja áður en sá sem borinn var sökum fékk að vita nákvæmlega hverjar sakargiftirnar voru. Áður en hann fékk að vita pað varð hann að skrifa undir trúnaðarsamning. Almenningur - ég meðtalin - sat uppi með pau hughrif að pessi maður væri ofbeldisfullur raðnauðgari og öllum var frjálst að ráđast opinberlega á hann pví að samkvæmt samningnum sem hann undirritaði var honum meinað að taka til varna. Fúkyrðahríðin lét ekki á sér standa.

En síðan, eftir rannsókn dómara sem stóð mánuðum saman, par sem skýrslur voru teknar af fjölda vitna, sagði dómarinn að pað hefði ekkert kynferðisofbeldi átt sér stað, ef marka má yfirlýsingu frá Galloway sem lögmaður hans birti. Starfsmaðurinn var rekinn engu að síður. Рað vakti furðu allra, líka mína. Starfsmannafélag háskólans lagði fram kæru sem enn er til meðferðar og meðan svo er fær almenningur ekki aðgang að skýrslu dómarans eða rökstuðningi hennar út frá framlögðum sönnunargögnum. Sumu fólki mislíkaði sýknudómurinn. Рað hélt árásunum áfram. Раð var um petta leyti sem pað fór að spyrjast út hversu gölluð málsmeðferð háskólans hafði verið og opna bréfið UBC Accountable varð til.

Nú myndi sanngjörn manneskja stilla sig um að dæma um sekt eða sakleysi par til skýrslan og sönnunargögnin lægju fyrir. Við erum fullorðið fólk. Við getum gert upp hug okkar á pennan veginn eða hinn. Petta hefur alltaf verið afstaða peirra sem skrifuðu undir opna bréfið. Pau sem gagnrýna mig eru á öðru máli pví pau eru pegar búin að gera upp hug sinn. Eru pessir góðu femínistar sanngjarnt fólk? Ef svo er ekki, pá eru pau bara að ala á peirri ævagömlu bábilju að konur séu ófærar um sanngirni eða yfirvegaða dómgreind, og um leið að gefa andstæðingum kvenna enn eina átyllu til að halda peim frá áhrifastöðum í heiminum. 
Útúrdúr: Nornatal. Annað atriði sem mér er fundið til foráttu er að ég bar málsmeðferð UBC saman við nornaréttarhöldin í Salem, par sem hver sá sem ákærður var taldist sekur af pví að reglur um sönnunarfærslu voru pannig að sýknudómur var ómögulegur. Góðu femínistarnir sem ásaka mig telja petta forkastanlegan samanburð. Pær halda að með pessu hafi ég verið að bera pær saman við nornaveiðara á táningsaldri í Salem og par með að kalla pær hysterískar smástelpur. Ég var hins vegar að vísa til fyrirkomulags sjálfra réttarhaldanna.

Nú um stundir er tal um „nornir“ af prennu tagi: 1) Að kalla einhvern norn, eins Hillary Clinton fékk óspart að kenna á í nýlegum kosningum. 2) „Nornaveiðar“ er haft um pað pegar einhver leitar að pví sem ekki er til. 3) Fyrirkomulag nornaréttarhaldanna í Salem, par sem ákæra nægði til sakfellingar. Рað var pessi priðja notkun sem ég átti við.

Petta fyrirkomulag - sekur vegna ákæru - hefur verið við lýði á mörgum öðrum skeiðum mannkynssögunnar en í Salem. Рað hefur gjarnan orðið ofaná á peim skeiðum byltinga sem kenna má við „ógn og dyggð“ - eitthvað hefur farið úrskeiðis og pað parf að hreinsa út, eins og í frönsku byltingunni, í hreinsunum Stalíns í Sovétríkjunum, á tímabili rauðu varðliðanna í Kína, á valdatíma herforingjanna í Argentínu og í upphafi byltingarinnar í Íran. Listinn er langur og bæði vinstri og hægri öfl hafa átt hlut að máli. Áður en skeiði „ógnar og dyggðar“ lýkur eru býsna margir fallnir í valinn. Athugið að ég er ekki að halda pví fram að pað séu ekki til neinir svikarar, eða hvaða hópur pað nú er sem spjótin beinast að; heldur einfaldlega að á slíkum tímum eru venjulegar reglur um sönnunarfærslu settar til hliðar.

Slíkt er alltaf gert í nafni pess að innleiða betri heim. Stundum heppnast pað, að minnsta kosti um stundarsakir. Stundum er petta notað sem átylla til að koma á kúgun af nýju tagi. Hvað varðar sjálftökuréttarfar - sakfellingu án dóms og laga - pá byrjar pað sem viðbragð við skorti á réttlæti. Annaðhvort er réttarkerfið spillt, eins og í Frakklandi fyrir byltinguna, eða pað fyrirfinnst ekkert kerfi, eins og í villta vestrinu - svo að fólk tekur málin í eigin hendur. En skiljanlegt og tímabundið sjálftökuréttarfar getur ummyndast í menningarlega fastmótaða hefð fyrir múgaftökum par sem tiltæku réttarfari er kastað út og valdakerfum utan dóms og laga komið á og peim viðhaldið. Cosa Nostra, mafían á Sikiley, byrjaði til dæmis sem andóf gegn pólitískri harðstjórn.

\#MeToo-hreyfingin er til marks um veilu í réttarkerfinu. Alltof oft 
fengu konur og önnur fórnarlömb kynferðisofbeldis ekki sanngjarna málsmeðferð hjá stofnunum - og pá eru stórfyrirtæki ekki undanskilin - svo pær tóku í pjónustu sína nýtt verkfæri: Internetið. Stjörnur hröpuðu af himni. Petta hefur reynst afar áhrifaríkt og vakið okkur rækilega til umhugsunar. En hvað svo? Рað er hægt að lagfæra réttarkerfið, ella gæti samfélagið látið pað lönd og leið. Stofnanir, fyrirtæki og vinnustaðir geta gert hreint fyrir sínum dyrum, annars mega pau búast við að fleiri stjörnur hrapi og fjöldinn allur af smástirnum að auki.

Ef réttarkerfið er lagt til hliðar af pví að pað pykir ekki skilvirkt, hvað tekur pá við? Hverjir munu pá miðla valdinu? Ekki verða pað vondir femínistar eins og ég. Hvorki hægri né vinstri öflin kæra sig um okkur. Á öfgafullum tímum verða öfgamennirnir ofan á. Hugmyndafræði peirra verður að trúarbrögðum, litið er á hvern pann sem ekki bergmálar skoðanir peirra sem trúníðing, villutrúarmann eða svikara og hófsömum miðjumönnum er tortímt. Skáld eru sérstaklega viðsjárverð pví pau skrifa um mannfólk og fólk er siðferðilega margrætt. Markmið hugmyndafræðinnar er að útrýma margræðni.

Opna bréfið UBC Accountable er líka til marks um veilu - veilu hjá Háskólanum í Bresku-Kólumbíu og í málsmeðferð hans. Borgararéttindasamtök í Bresku-Kólumbíu og á landsvísu hefðu átt að láta málið til sín taka. Kannski taka pau við sér núna. Ekki síst af pví að nú er farið að tala um ritskoðun í tengslum við petta bréf - pað er kallað eftir pví að vefsíðunni verði eytt og með henni mörgum og ígrunduðum orðum bréfritaranna - kannski kanadíski PEN-klúbburinn, albjóðlegi PEN-klúbburinn, Kanadísku blaðamannasamtökin um tjáningarfrelsi (e. CFFE) og Ritskoðunarvaktin (e. Index on Censorship) hafi líka eitthvað um petta að segja.

Í bréfinu sagði frá upphafi að UBC hefði brugðist bæði peim ákærða og kærendunum. Ég myndi bæta pví við að háskólinn hefði brugðist skattgreiðendum sem árlega leggja honum til um 600 milljónir dollara. Við vildum gjarnan fá að vita hvernig fjármunum okkar var varið parna. Styrktaraðilar UBC - en háskólinn fær milljarða dollara í framlögum frá einkaaðilum - eiga einnig rétt á að vita petta.

Í pessu máli öllu hefur rithöfundum verið att saman, ekki síst með pví að afbaka efni bréfsins og ófrægja pað sem stríð gegn konum. En nú skora ég á alla - jafnt góða femínista og vonda femínista eins og sjálfa mig - að láta af ófrjóu argaprasi, taka höndum saman og beina kastljósinu pangað 
sem pað átti alltaf að skína - á UBC. Tveir meðkærendanna eru nú búnir að fordæma hvernig UBC hefur haldið á málinu. Fyrir pað eiga pær pakkir skildar.

Pegar UBC hefur komið af stað sjálfstæðri rannsókn á eigin gjörðum í líkingu við pá sem nýlega var framkvæmd í Wilfrid Laurier-háskólanum - og hefur heitið að gera niðurstöðurnar opinberar, verður vefsíðan $U B C$ Accountable búin að pjóna tilgangi sínum. Раð var aldrei tilgangur hennar að traðka á konum. Af hverju er látið í veðri vaka að ábyrgð og gegnsæi séu andstæð kvenréttindum?

Stríð meðal kvenna, fremur en stríð gegn konum, er alltaf ánægjuefni fyrir bá sem ekki vilja konum vel. Petta er afar mikilvægt augnablik. Ég vona að pví verði ekki sólundað.

[Birtist í The Globe and Mail í Toronto 13. janúar 2018] Aðalsteinn Eypórsson pýddi

\section{Margaret Atwood}

Skáld og rithöfundur

AĐalsteinn Eybórsson

Íslenskufræðingur

adalsteinn.e@gmail.com 